Павелко О. В. [1; ORCID ID: 0000-0002-2483-2245], к.е.н., доцент,

Велігурська А. М. [1; ORCID ID: 0000-0002-4261-9739], здобувач вищої освіти першого (бакалаврського) рівня

'Національний університет водного господарства та природокористування, м. Рівне

\title{
МЕХАНІЗМ КРЕДИТУВАННЯ ПОЗИЧАЛЬНИКІВ БАНКАМИ В СУЧАСНИХ ЕКОНОМІЧНИХ РЕАЛІЯХ
}

\begin{abstract}
Статтю присвячено дослідженню особливостей банківського кредитування на сучасному етапі. Розглянуто сутність понять «банківський кредит» та «банківське кредитування». Виділено етапи кредитного процесу банку для надання позик позичальникам. Ідентифіковано значення, завдання та основні складові кредитної політики банку. Досліджено причини негативної динаміки кількості комерційних банків в Україні за період 2016-2020 рр. Виявлено зниження частки кредитного портфеля у структурі валового внутрішнього продукту з 2016 по 2019 рр. Розглянуто динаміку структури кредитування в розрізі видів діяльності та цілей кредитів. Охарактеризовано особливості Державної програми «Доступні кредити 57-9\%», що дозволяє покривати поточні потреби та фінансувати масштабні проєкти. Проаналізовано зниження процентних ставок за депозитами та позиками впродовж III кварталу 2020 р. Висвітлено рекомендації Національного банку України комерційним банкам щодо полегшення фінансового тягаря для позичальників та підвищення ефективності управління проблемною кредитною заборгованістю у зв'язку із значним падінням доходів позичальників, спричиненим режимом ізоляції. Охарактеризовано причини зменшення частки «непрацюючих» банківських кредитів у 2020 р.

Ключові слова: банківська система; комерційний банк; кредит; кредитна політика; кредитний портфель; Державна програма «Доступні кредити 5-7-9\%»; процентна ставка; «непрацюючі кредити».
\end{abstract}

Актуальність теми. В сучасних доволі непростих реаліях перед економікою України постав новий виклик - фінансова криза, що $є$ наслідком обмежувальних заходів, впроваджених для протидії поширенню вірусу: знижено економічну активність у сфері обслуговування та розваг, роздрібної торгівлі непродовольчими товарами, готельно-ресторанного бізнесу, транспорту; зростає рівень безробіття, зменшуються обсяги експорту та імпорту; збільшується дефіцит бюджету. Безперечно, стабільність економіки значною 
мірою залежить від дій уряду, спрямованих на пом'якшення негативних впливів, спричинених карантинними заходами. Проте, важливу роль відіграє і банківський сектор країни, який забезпечує акумулювання та перерозподіл грошей у ті сфери виробництва та обігу, де виникає дефіцит капіталу, шляхом кредитування суб'єктів господарювання. Банківський кредит в умовах недостатності власних коштів для здійснення виробництва нерідко постає основним джерелом поповнення оборотного капіталу підприємств. За таких обставин банківська система здатна забезпечити рух капіталу, розвиток підприємницької діяльності, неперервність розширеного відтворення та сприяти оперативному подоланню кризових явищ в економіці. Відтак, дослідження механізму банківського кредитування та стану ринку надання кредитних послуг є вкрай актуальним.

Аналіз останніх досліджень і публікацій. Висвітленню сутності процесу кредитування та діяльності банку на ринку надання кредитних послуг присвячено праці багатьох вітчизняних фахівців, зокрема Н.І. Волкової, В. А. Кульбіди [2], Д. М.Гладких [3], Л. А. Зверук, Т. С. Лисенко [4], Н. П. Погореленко, А. Ю. Юрченко [5] та ін. Проте, зазначені питання розглянуто недостатньо. Малодослідженими лишаються тенденції розвитку банківського кредитування в умовах фінансової кризи 2020 р.

Постановка завдання. Метою статті $€$ дослідження основних етапів процесу надання банківських кредитів, ідентифікація завдань та виокремлення найважливіших компонентів кредитної політики банків, огляд і аналіз змін показників кредитної діяльності банків України в сучасних економічних реаліях.

Викладення основного матеріалу. Згідно із Законом України «Про банки і банківську діяльність» від 07.12.2000 № 2121-ІІІ банківський кредит - це будь-яке зобов'язання банку надати певну суму грошей, будь-яка гарантія, будь-яке зобов'язання придбати право вимоги боргу, будь-яке продовження строку погашення боргу, яке надано в обмін на зобов'язання боржника щодо повернення заборгованої суми, а також на зобов'язання на сплату процентів та інших зборів з такої суми [1]. Досить вдало визначення кредиту ілюструє у своїй праці проф. Л.М.Кіндрацька (рис. 1). Банківський кредит, за переконаннями вітчизняних науковців, це: позичковий капітал банку у грошовій формі, що передається у тимчасове користування на засадах строковості, повернення, платності, забезпеченості та цільового використання [12, С. 77]; форма позичкового капіталу (в грошовій або товарній формах), що надається на умовах повернення і обумовлює виникнення кредитних 
відносин між тим, хто надає кредит, і тим, хто його отримує [14]; суспільні відносини, що виникають між економічними суб'єктами у зв'язку з переданням один одному в тимчасове користування вільних коштів (вартості) на засадах зворотності, платності та добровільності [13].

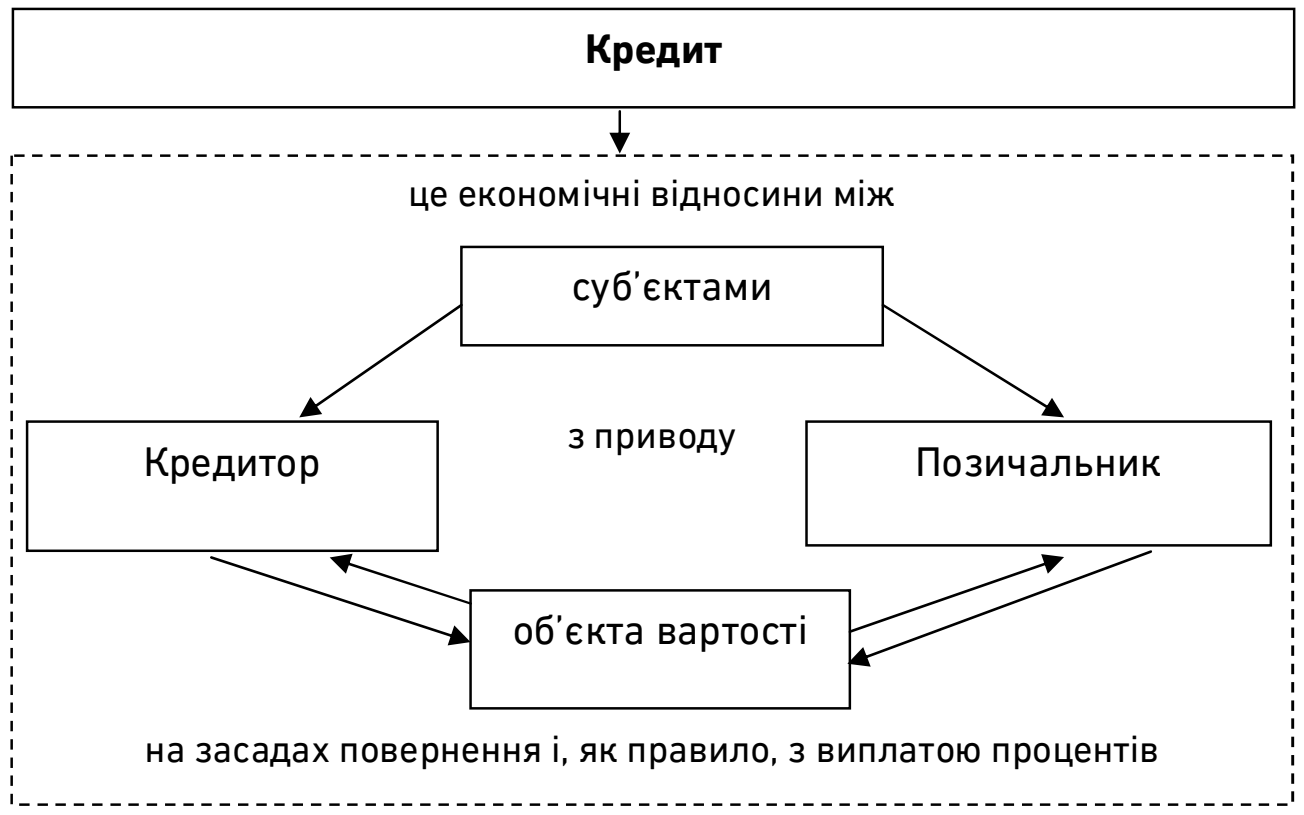

Джерело: [11].

Рис. 1. Визначення кредиту

Згідно 3 трактуваннями, визначеними у Міжнародних стандартах фінансової звітності, надані банками кредити відносяться до категорії фінансових активів, які $€$ одним із видів фінансових інструментів. Відповідно до МСБО 32 «Фінансові інструменти: подання» [16] фінансовий актив - це будь-який актив, що є:

а) грошовими коштами;

б) інструментом власного капіталу іншого суб'єкта господарювання;

в) контрактним правом:

- отримувати грошові кошти або інший фінансовий актив від іншого суб'єкта господарювання або

- обмінювати фінансові інструменти 3 іншим суб'єктом господарювання за умов, які $є$ потенційно сприятливими, або

г) контрактом, розрахунки за яким здійснюватимуться або можуть здійснюватися власними інструментами капіталу суб'єкта господарювання та який $є$ :

- непохідним інструментом, за який суб'єкт господарювання 
зобов'язаний або може бути зобов'язаний отримати змінну кількість власних інструментів капіталу суб'єкта господарювання, або

- похідним інструментом, розрахунки за яким здійснюватимуться або можуть здійснюватися іншим чином, ніж обміном фіксованої суми грошових коштів або іншого фінансового активу на фіксовану кількість власних інструментів капіталу суб'єкта господарювання.

Чинним банківським законодавством України кредитні операції визначаються як вид активних банківських операцій, пов'язаних із розміщенням залучених банком коштів таким шляхом: надання їх у тимчасове користування або прийняття зобов'язань про надання певної суми коштів; надання гарантій, порук, акредитивів, акцептів, авалів; розміщення депозитів; проведення факторингових операцій та операцій фінансового лізингу; видача кредитів у формі врахування векселів, у формі операцій зворотного репо; будь-якого продовження строку погашення боргу, яке надано в обмін на зобов'язання боржника щодо повернення заборгованої суми, а також на зобов'язання щодо сплати процентів та інших зборів за такою сумою (відстрочення платежу); розстрочення платежу за продані банком активи [15].

Слід розрізняти поняття «банківський кредит» і «банківське кредитування», оскільки останнє становить собою форму руху позичкового капіталу, в якій посередником виступає банк, котрий водночас $\epsilon$ кредитором i позичальником. Під механізмом кредитування розуміється поетапність видачі кредитів комерційними банками та сукупність умов, що зумовлюють таку видачу на кожному етапі кредитування. Процес банківського кредитування передбачає етапи, кожен із яких самостійно задовольняє рішення локального завдання, а всі етапи разом допомагають в досягненні головної мети позичкових операцій - їх прибутковості та надійності для банку [2, С. 115].

Існують різні способи розмежування цих етапів, однак, спільним $€$ виділення попереднього, підготовчого, основного та заключного етапів. Попередній етап полягає в обґрунтуванні доцільності розгляду кредитної заявки, а саме у проведенні попередніх переговорів із позичальником, протягом яких з'ясовуються цілі, джерела погашення кредиту, кредитна історія позичальника, отримується інформація про наявність рахунків в інших банках, оборотів по них. Відбувається ознайомлення із структурою, вартістю активів підприємства, можливими варіантами забезпечення кредиту. Підготовчий етап передбачає кількісне оцінювання рішення, тобто оцінювання кредитоспроможності 
клієнта, віднесення його до відповідного класу за рейтингом надійності, вивчення установчих документів, аналіз фінансової звітності, бізнес-плану, маркетингове дослідження попиту на продукцію позичальника [2, С. 115]. На основному етапі розробляються умови кредитної угоди (договору), здійснюється їх коригування (за потреби), підписання кредитної угоди, формування кредитного досьє, реєстрація, підготовка та передача розпорядження в операційний відділ та безпосередній процес надання кредиту. Заключний етап полягає у супроводженні кредиту (контроль за його використанням, збереженням предмета застави), реалізації відповідної стратегії щодо проблемного кредиту (за наявності ознак проблемності кредиту), поверненні кредиту і отриманні відсотків за його надання позичальнику.

Крім послідовного виконання завдань, передбачених кожним етапом, важливо забезпечити їх деталізацію, виокремити обов'язки та відповідальність окремих посадових осіб, які забезпечують реалізацію відповідного етапу кредитування. Саме тому необхідним $\epsilon$ розроблення кредитної політики, яка б визначала стандарти, параметри і процедури, якими б керувались банківські працівники під час надання, оформлення кредитів і управління кредитними ризиками.

Варто зазначити, що кредитна політика банку представлена у вигляді документу «Положення про кредитну політику», що визначає основні принципи і стандарти кредитної діяльності; встановлює відповідальність та повноваження працівників банку на кожному етапі кредитного процесу; встановлює загальний підхід банку до прийняття кредитних ризиків; забезпечує комплексний підхід до управління ризиками. Кредитна політика, як нормативний документ, визначає основні вектори управління кредитною діяльністю банку, які представлені такими їі підрозділами: клієнти та продукти, валюта фінансування, цільові галузі для фінансування, ухвалення новацій та змін, обробка виключних ситуацій (ризик-менеджмент), основні принципи кредитування, організація кредитного процесу, мінімальні вимоги до потенційних позичальників, мінімальні стандарти кредитної угоди, кредитні повноваження, моніторинг кредитів, економічні заходи в роботі з проблемними кредитами, звітність [4, C. 351].

Важливою умовою формування кредитної політики, здатної забезпечити ефективну реалізацію механізму кредитування, $\epsilon$ дотримання вимог чинного законодавства, огляд основних структурних зрушень, змін, тенденцій на ринку кредитних послуг, аналіз реальних економічних умов, що прямо та опосередковано 
впливають на процес надання кредиту. В Україні впродовж декількох років спостерігається зменшення кількості діючих банків, банків з іноземним капіталом, проте, відбувається збільшення числа банків зі 100\% іноземним капіталом (таблиця). Окремі науковці зазначають, що зменшення кількості банків зумовлене внесенням змін до Закону України «Про банки і банківську діяльність» від 07.12.2000 № 2121-III, а саме підвищенням вимог до мінімального розміру статутного капіталу новостворюваних банків - із 120 до 500 млн грн. Діючі банки повинні були протягом 10 років 3 дня набрання чинності нової редакції Закону привести розмір статутного капіталу відповідно до вимог, зазначених вище. Проте, згідно 3 визначеним НБУ графіком до 11.07.2017 р. статутний капітал банків повинен був становити не менше, ніж 200 млн грн. Однак, у червні 2020 р. мінімальний розмір статутного капіталу банків знижено з 500 до 200 млн грн [8].

Таблиця

Динаміка кількості банків України впродовж 2016-2020 рр.

\begin{tabular}{|l|c|c|c|c|c|}
\hline \multicolumn{1}{|c|}{ Показники, од. } & 201 & 201 & 201 & 201 & 202 \\
& 6 & 7 & 8 & 9 & 0 \\
\hline 1. Кількість діючих банків, в т.ч. & 96 & 82 & 77 & 75 & 74 \\
\hline 1.1. з іноземним капіталом & 38 & 38 & 37 & 35 & 33 \\
\hline 1.1.1. зі 100 \% іноземним капіталом & 17 & 18 & 23 & 23 & 22 \\
\hline
\end{tabular}

Джерело: [6]. Дані станом на 01.11.2020 р.

Серед причин зменшення кількості діючих банків можна виділити і неспроможність нейтралізувати ризики, а також недостатність ресурсної бази. Загалом банківська система України представлена двома рівнями: перший рівень належить НБУ, другий всім іншим банкам України. Своєю чергою банки поділяються на приватні, кооперативні, банки з іноземним капіталом. Нині існує значна кількість ознак, за якими проводиться класифікація банків. Сучасним явищем у банківській системі $є$ поява віртуальних банків, до прикладу «Monobank», який в рейтингу, що формується щодня за результатами відгуків відвідувачів порталу «minfin.com.ua» про оцінку діяльності роботи банків, посідає перше місце. Для формування загального рейтингу банків ураховуються показники реагування та вирішення банками проблем своїх клієнтів, а також береться до уваги оцінка діяльності банків клієнтами. Всі банки України $є$ економічно незалежними структурними одиницями, які активно кредитують фізичних та юридичних осіб.

Частка кредитного портфеля банків у ВВП України з кожним роком зменшується (рис. 2). На кінець 2019 р. вона склала лише 
$28,12 \%$, що опосередковано свідчить про зменшення кредитних вкладень у фінансування галузей економіки [5, С. 327]. Як наслідок, послаблення кредитування ускладнює стимулювання економічного зростання. Одним із чинників такої негативної тенденції $\epsilon$ збільшення доходів, що зумовлює низьку середню закредитованість населення, що може забезпечити значний потенціал відновлення кредитування. Впродовж останніх років в країні спостерігається згортання кредитної активності в сегменті кредитів, наданих суб'єктам господарювання (порівняно з 2016 р. відбулося зменшення на 5,24 в.п.), та незначне збільшення порівняно з 2016 р. - стосовно кредитів, наданих органам державної влади (збільшення на 0,48 в.п.) та фізичним особам (збільшення на 4,76 в.п.) (рис. 3). Однак, слід підмітити, що водночас зі скороченням діяльності у сфері кредитування поступово зростає обсяг вкладень в цінні папери та довгострокові інвестиції. Зазначене обґрунтовується тим, що другий варіант розміщення ресурсів $\epsilon$ менш ризиковим, на відміну від першого.

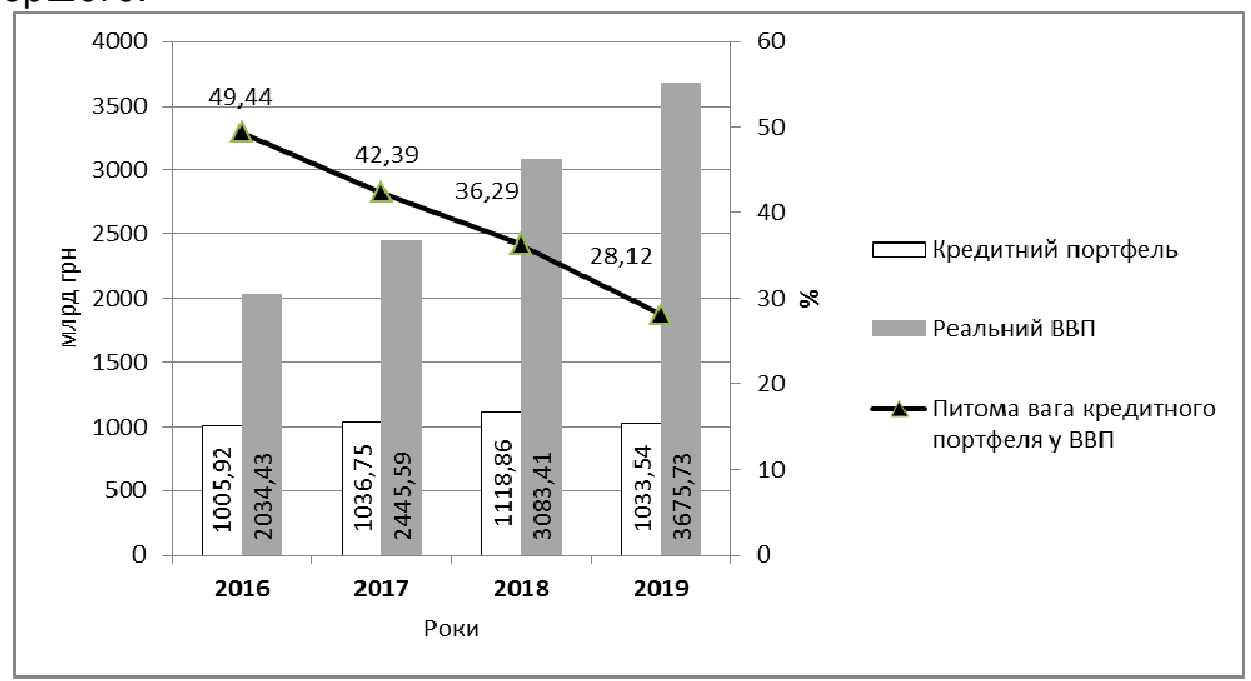

Рис. 2. Співвідношення кредитного портфеля банків України до ВВП за 2016-2019 рр.

Джерело: [5, С. 327]. 


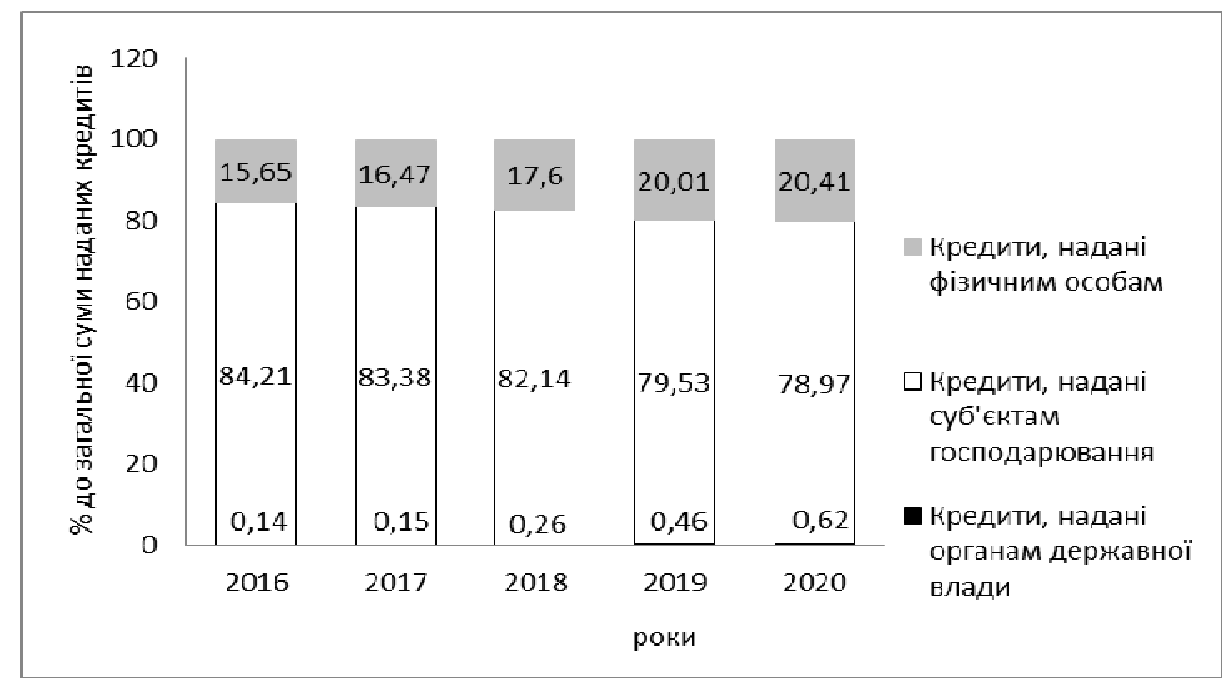

Рис. 3. Співвідношення кредитів, наданих фізичним особам, суб'єктам господарювання та органам державної влади до загальної суми наданих кредитів за 2016-2020 рр. Джерело: [6]. Дані станом на 01.11.2020 p.

Розподіл кредитів згідно з видами економічної діяльності позичальників свідчить про домінування кредитів (станом на 01.06 .2020 р.) у сферу торгівлі (зростання до $37,1 \%$ ), переробну промисловість (скорочення до 23,7\%), сільське господарство (зростання до 8,4\%). Натомість галузі, що могли б стати локомотивами відновлення економіки, відчувають дефіцит кредитування: будівництво (3,2\%), транспорт (4,2\%), інформація та телекомунікації (0,8\%) [3, С. 225]. Доцільно звернути увагу на урядову програму «Доступні кредити 5-7-9\%», розроблену відповідно до Порядку надання фінансової державної підтримки суб'єктам мікропідприємництва та малого підприємництва, затвердженого Постановою Кабінету Міністрів України від 24.01.2020 р. № 28. У програмі задіяно 16 банків 374 існуючих в Україні, які не зможуть одержати надприбутки, беручи участь в даній програмі. Цілями, на які надаються кредити, $€$ впровадження господарської діяльності суб'єктів мікро- та малого підприємництва (інвестиційні цілі) та рефінансування їх заборгованості за отриманими кредитами. Суб'єкти господарювання можуть стати учасниками програми протягом строку дії карантину або обмежувальних заходів та впродовж 90 днів з дня його (ї) відміни. Максимальна сума кредиту $\epsilon$ необмеженою, проте, необхідно враховувати обмеження щодо Ліміту державної допомоги, що становить 200 тис. євро. Максимальний строк кредитування залежить від цілей, на досягнення яких буде витрачено кошти, та становить 60 або 
24 місяці [10]. У структурі кредитів, наданих фізичним особам за III квартал 2020 р., зміни не спостерігаються. Найбільшою часткою характеризуються споживчі кредити до 1 року (53,9\%) та від 2 до 5 років $(16,7 \%)$ (рис. 4).

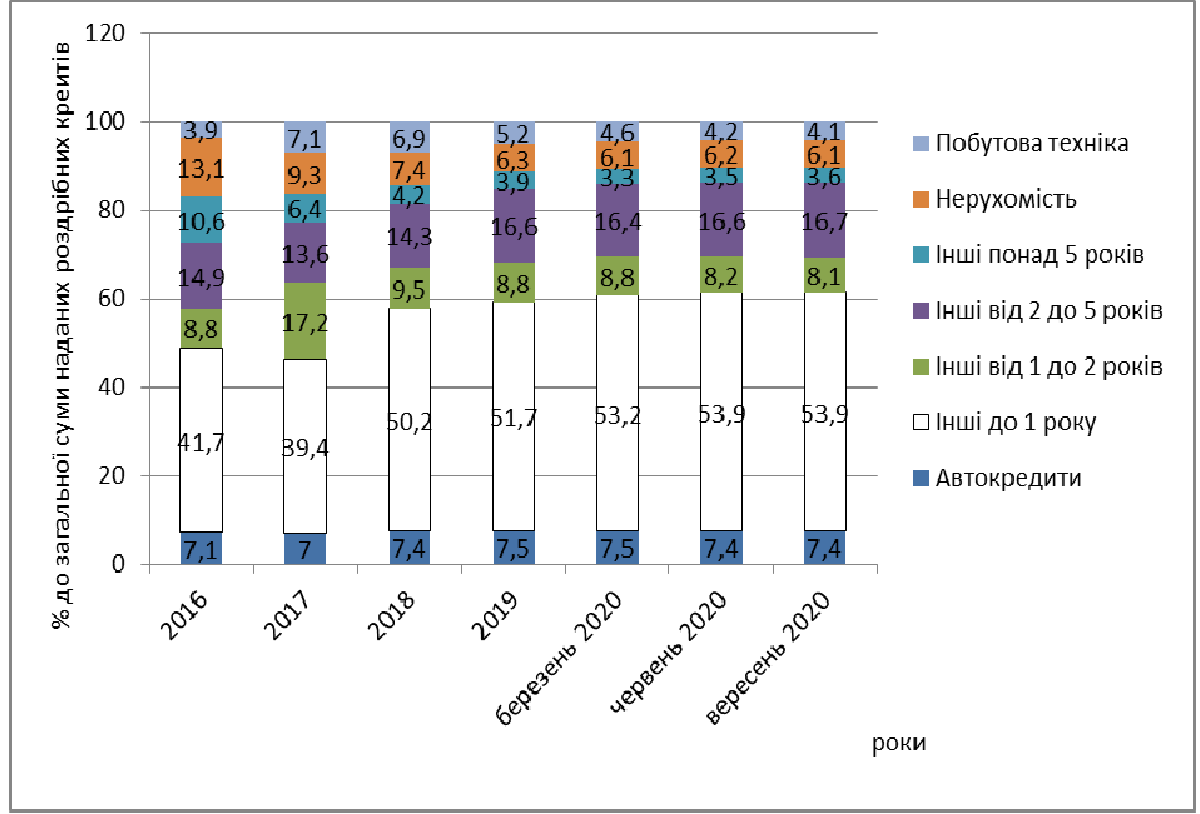

Рис. 4. Структура валових гривневих кредитів, наданих домашнім господарствам за цільовим призначенням

Джерело: [9, С. 6].

3 кінця 2017 р. відбувається зниження частки кредитів на придбання побутової техніки (з 7,1\% до 4,1\%). 3 кінця 2016 р. до березня 2020 р. частка кредитів на придбання, будівництво та реконструкцію нерухомості знизилась на 7 в.п. (з 13,1\% до 6,1\%). Частка споживчих кредитів понад 5 років поступово зменшувалася. 3 10,6\% до 3,3\%. Протягом 2017-2018 рр. частка кредитів від 2 до 5 років зменшилася, однак, з 2019 р. вона майже не змінилася. Частка кредитів від 1 до 2 років знизилася з кінця 2017 р. до вересня 2020 р. на 9,1 в. п. (з 17,2\% до 8,1\%). Впродовж 2017 р. частка кредитів до 1 року знизилась на 2,3 в.п., проте, далі вона невпинно зростала (з 39,4 до 53,9\%). Частка автокредитів зросла протягом 2018-2019 рр. з 7\% до 7,5\% та залишилась практично незмінною.

Слід відмітити, що сповільнення інфляції від початку 2020 р. (до 1,7\% у травні 2020 р.) та рівень інфляції, що є нижчим цільового діапазону НБУ, дозволили НБУ знизити облікову ставку до 6\% (на 7,5 в.п.). Така ситуація $€$ унікальною в історії України, оскільки попередні кризи супроводжувалися стрімким зростанням рівня інфляції, тому НБУ був змушений застосовувати більш жорстку 
монетарну політику [7, С. 11]. Низькі темпи інфляції, стабільні інфляційні очікування, довіра до банківського сектору та зниження облікової ставки НБУ є передумовами для зниження депозитних ставок. За відсутності нових макроекономічних показників спостерігатиметься зниження вартості кредитів для суб'єктів господарювання та фізичних осіб.

Вартість 12-місячних гривневих депозитів фізичних осіб за III квартал 2020 р. знизилася до 8,7\% річних (на 0,9 в.п.), у доларах США - коливалася близько 1,3\% річних. Спред між 3-місячними та 12-місячними депозитами у гривнях несуттєво зріс - 3 0,2 в.п. до 0,5 в.п., проте це не створювало стимулів для продовження строковості депозитів. Гривневі кошти корпорацій подешевшали до 3,8\% річних (на 1,4 в.п.). Середні ставки за кредитами суб'єктам господарювання у гривнях за III квартал скоротилися до 9,6\% річних (на 1,0 в.п.), а за кредитами фізичним особам - до $30,9 \%$ річних (на 1,9 в.п.). Вартість валютних кредитів бізнесу становила близько 5\% річних [9, С. 2].

Значне зниження економічної активності внаслідок карантинних заходів призвело до скорочення доходів населення та погіршення фінансового стану підприємств. Це ускладнює обслуговування позик та спричиняє погіршення якості кредитного портфеля банків. Реалізація кредитного ризику банків може спровокувати загрозу достатності капіталу окремих банків. НБУ рекомендовано реструктуризувати кредити таким позичальникам та пом'якшено вимоги до оцінки кредитного ризику, адже реструктуризовані кредити не чинитимуть негативний вплив на капітал банків. Згідно зі Звітом про фінансову стабільність НБУ від 22 червня 2020 р. для $11 \%$ позик запропоновано полегшені умови. П'ять вітчизняних банків забезпечили майже всі реструктуризації, їм належить половина кредитного портфеля країни. За результатами опитування банків, відомо, що ті не збільшили резерви за роздрібними кредитами попри розгортання глибокої кризи. Це призводить до одномоментного формування резервів у значних обсягах в майбутньому і створення так званого «ефекту обриву» (cliff effect) для показників прибутковості та достатності капіталу. Від початку кризи банки запропонували позичальникам «кредитні канікули», що дає можливість відтермінувати витрати на обслуговування позик. Крім того, для тимчасового зниження витрат на обслуговування боргу банки можуть використовувати капіталізацію відсотків за позиками. Тому для позичальників, доходи яких значно знизились у період кризи, може підвищитись рівень боргового зобов'язання [7, С. 19, 30-31]. 
Частка непрацюючих кредитів (усі, в тому числі міжбанківських) зменшилася за III квартал 2020 р. до 45,6\% кредитного портфеля (при розрахунку враховано усі банки, в тому числі неплатоспроможні, без позабалансових зобов'язань) (на 2,9 в.п.). На кінець III кварталу 2020 р. частка непрацюючих кредитів, наданих суб'єктам господарювання, становила $50,9 \%$ кредитного портфеля, а непрацюючих кредитів, наданих фізичним особам - 34,8\%. Головним чинником, що вплинув на показник, було списання з балансу повністю зарезервованої заборгованості, за якою банки не очікують надходжень, відповідно до вимог НБУ. Як наслідок, рівень покриття загальними резервами непрацюючих кредитів за III квартал 2020 року підвищився до найвищого 32014 р. рівня у 97,6\% (на 0,7 в.п.) $[9$, С. 6]. Проте, банківський сектор оперативно реагує на кризу 2020 р. та підтримує кредитування завдяки високому запасу міцності, операційній ефективності, прибутковості та вчасним регуляторним діям НБУ.

Активізація банківського кредитування в сучасних економічних реаліях уможливлюється через скорочення рівня ризиковості інвестиційних кредитів та вдосконалення підходів до управління наявними ризиками, процес мінімізації яких передбачає їх ідентифікацію, виявлення джерел і встановлення обсягів інформації, потрібних для оцінювання рівня ризиків; обрання критеріїв i визначення методів оцінювання їх рівня; проведення аналізу результатів управління ризиками. Державна політика, передусім, має бути спрямованою на стимулювання інвестиційної активності, заохочення інвестицій в економіку, забезпечення стійкості банківського сектору, підвищення якості банківських функцій в частині акумулювання коштів фізичних осіб і суб'єктів господарювання та їх трансформації в кредити й інвестиції; нарощування довіри до банків 3 боку інвесторів і вкладників; посилення захисту їх інтересів; створення нових механізмів рефінансування 3 урахуванням досвіду банків 3 іноземним капіталом. Розвиток банківського сектору і активізація кредитних операцій банків не можуть відбуватися за відсутності політичної та економічної стабільності в країні. У вирішенні окреслених завдань ключова роль має відводитися, без винятку, усім гілкам державної влади.

Висновки і перспективи подальших розвідок. Отже, механізм кредитування передбачає такі етапи, як: попередній, підготовчий, основний та заключний етапи, які включають оцінку кредитоспроможності позичальника, прийняття рішення щодо 
надання кредиту, укладання кредитної угоди (договору), надання кредиту, контроль за його використанням та його повернення. Невід'ємним елементом здійснення кредитної діяльності $\epsilon$ формування кредитної політики, що забезпечує деталізацію та прозорість завдань на кожному етапі надання кредиту, ефективне розміщення коштів банку та дієвий контроль за кредитними ризиками. В Україні спостерігається зниження кредитної активності банків вподовж останніх років, що перешкоджає стимулюванню окремих галузей економіки, натомість, зростає частка вкладень в цінні папери.

Загалом діяльність банків та стан економіки країни безперечно залежать від виваженої державної політики. Держава повинна не лише розробляти грошово-кредитну та інвестиційну політику, а й безпосередньо брати участь в їх реалізації, передбачаючи в бюджеті відповідні кошти з цією метою і використовуючи їх винятково за цільовим призначенням. Нині економічна стратегія держави повинна передбачати забезпечення збалансованості грошово-кредитної політики і дії механізмів іiї реалізації та бути спрямованою на усунення протиріч між тенденціями розвитку різних напрямів грошово-кредитних відносин, а також невідповідностей, які виникли між потребами реального сектору економіки і наявним фінансовим ринком. Подальші дослідження авторів будуть спрямовані на здійснення комплексного аналізу наслідків фінансової кризи 2020 р. для банківського сектору України.

1. Про банки і банківську діяльність: Закон України від 07.12.2000 № 2121-ІІІ. Дата оновлення: 03.07.2020. URL: https://zakon.rada.gov.ua/laws/show/2121-14\#Text (дата звернення: 14.12.2020). 2. Волкова Н.І., Кульбіда В. А. Особливості банківського кредитування підприємств на сучасному етапі. Фінанси, облік, банки. 2019. № 1 (24). С. 113-122. 3. Гладких Д. М. Чинники оздоровлення кредитного портфеля та відновлення банківського кредитування в Україні. Бізнес Інформ. 2020. № 7. С. 224-230. 4. Зверук Л. А., Лисенко Т. С. Управління кредитною діяльністю банківських установ: сутність, практика, напрями вдосконалення. Бізнес Інформ. 2019. № 1. С. 349-357. 5. Погореленко Н. П., Юрченко А. Ю. Оцінка процесів управління кредитним портфелем АТ КБ «ПриватБанк». Бізнес Інформ. 2020. № 10. C. 325-332. 6. Дані наглядової статистики. Національний банк України. URL: https://bank.gov.ua/ua/statistic/supervision-statist/data-supervision\#1 (дата звернення: 14.12.2020). 7.Звіт про фінансову стабільність. Національний банк України. Червень 2020 р. https://bank.gov.ua/admin_uploads/article/FSR_2020-H1.pdf?v=4 (дата звернення: 22.06.2020). 8. Змінено вимоги до мінімального розміру регулятивного капіталу банку. Національний банк України. URL: https://bank.gov.ua/ua/news/all/zminenovimogi-do-minimalnogo-rozmiru-regulyativnogo-kapitalu-banku (дата звернення: 19.06.2020). 9. Огляд банківського сектору. Національний банк України. Листопад 2020 p.

C. 1-12.

URL: 
https://bank.gov.ua/admin_uploads/article/Banking_Sector_Review_2020-11.pdf?v=4 (дата звернення: 14.12.2020). 10.Програма «Доступні кредити 5-7-9\%». URL: https://5-7-9.gov.ua (дата звернення: 03.07.2020). 11. Кіндрацька Л. М. Фінансовий та управлінський облік у банках : підручник. К. КНЕУ, 2009. 816 с. 12. Волкова І. А. Бухгалтерський облік у банках: навч. посіб. К. : Центр учбової літератури, 2011. 520 с. 13. Банківські операції / Мороз А. М., Савлук М. І., Пуховкіна М. Ф. та ін. К. : КНЕУ, 2000. 384 с. 14. Фінанси підприємств / за ред. проф. А. М. Поддєрьогіна. К. : КНЕУ, 2001. 460 с. 15. Литвин Н. Б. Фінансовий облік у банках (у контексті МСФЗ). К. : «Центр учбової літератури», 2017. 676 с. 16. МСБО 32 «Фінансові інструменти: подання». URL: https://zakon.rada.gov.ua/laws/show/929_029 (дата звернення: 03.07.2020).

\section{REFERENCES:}

1. Pro banky i bankivsku diialnist: Zakon Ukrainy vid 07.12.2000 № 2121-III. Data onovlennia: 03.07.2020. URL: https://zakon.rada.gov.ua/laws/show/2121-14\#Text (data zvernennia: 14.12.2020). 2. Volkova N. I., Kulbida V. A. Osoblyvosti bankivskoho kredytuvannia pidpryiemstv na suchasnomu etapi. Finansy, oblik, banky. 2019. № 1 (24). S. 113-122. 3. Hladkykh D. M. Chynnyky ozdorovlennia kredytnoho portfelia ta vidnovlennia bankivskoho kredytuvannia v Ukraini. Biznes Inform. 2020. № 7. S. 224230. 4. Zveruk L. A., Lysenko T. S. Upravlinnia kredytnoiu diialnistiu bankivskykh ustanov: sutnist, praktyka, napriamy vdoskonalennia. Biznes Inform. 2019. № 1. S. 349-357. 5. Pohorelenko N. P., Yurchenko A. Yu. Otsinka protsesiv upravlinnia kredytnym portfelem AT KB «PryvatBank». Biznes Inform. 2020. № 10. S. 325-332. 6. Dani nahliadovoi statystyky. Natsionalnyi bank Ukrainy. URL: https://bank.gov.ua/ua/statistic/supervision-statist/data-supervision\#1 (data zvernennia: 14.12.2020). 7. Zvit pro finansovu stabilnist. Natsionalnyi bank Ukrainy. Cherven 2020 r. S. 1-51. URL: https://bank.gov.ua/admin_uploads/article/FSR_2020H1.pdf?v=4 (data zvernennia: 22.06.2020). 8. Zmineno vymohy do minimalnoho rozmiru rehuliatyvnoho kapitalu banku. Natsionalnyi bank Ukrainy. URL: https://bank.gov.ua/ua/news/all/zmineno-vimogi-do-minimalnogo-rozmiru-

regulyativnogo-kapitalu-banku (data zvernennia: 19.06.2020). 9. Ohliad bankivskoho sektoru. Natsionalnyi bank Ukrainy. Lystopad 2020 r. S. 1-12. URL: https://bank.gov.ua/admin_uploads/article/Banking_Sector_Review_2020-11.pdf?v=4 (data zvernennia: 14.12.2020). 10. Prohrama «Dostupni kredyty 5-7-9\%». URL: https://5-7-9.gov.ua (data zvernennia: 03.07.2020). 11. Kindratska L. M. Finansovyi ta upravlinskyi oblik u bankakh : pidruchnyk. K. : KNEU, 2009. 816 s. 12. Volkova I. A. Bukhhalterskyi oblik u bankakh : navch. posib. K. : Tsentr uchbovoi literatury, 2011. 520 s. 13. Bankivski operatsii / Moroz A. M., Savluk M. I., Pukhovkina M. F. ta in. K. : KNEU, 2000. 384 s. 14. Finansy pidpryiemstv / za red. prof. A. M. Poddierohina. K. : KNEU, 2001. 460 s. 15. Lytvyn N. B. Finansovyi oblik u bankakh (u konteksti MSFZ). K. : «Tsentr uchbovoi literatury», 2017. 676 s. 16. MSBO 32 «Finansovi instrumenty: podannia» URL: https://zakon.rada.gov.ua/laws/show/929_029 (data zvernennia: 03.07.2020). 
Pavelko O. V. [1; ORCID ID: 0000-0002-2483-2245], Candidate of Economics (Ph.D.), Associate Professor, Velihurska A. M. [1; ORCID ID: 0000-0002-4261-9739], Senior Student

${ }^{1}$ National University of Water and Environmental Engineering, Rivne

\section{LENDING MECHANISM FOR BORROWERS BY BANKS IN MODERN ECONOMIC REALITIES}

The article is devoted to the study of the peculiarities of bank lending at the present stage. The essence of the concepts «bank credit» and «bank lending» is considered. The interpretation of the loan by domestic scholars and the Law of Ukraine «On Banks and Banking» is analyzed. The essence of financial assets under IAS 32 «Financial Instruments: Presentations» is considered. The stages of the bank's credit process for providing loans to borrowers are highlighted. The essence of the preliminary, preparatory, main and final stages is investigated. The significance, tasks and main components of the bank's credit policy are identified. The components of the Regulation on the bank's credit policy are considered. The requirements to the size of the authorized capital of the bank are analyzed. The reasons for the negative dynamics of the number of commercial banks in Ukraine for the period 2016-2020 are studied. The decrease in the share of the loan portfolio in the structure of gross domestic product from 2016 to 2019 is revealed.

The peculiarities of the State Program «Affordable Loans 5-7-9\%» are described, which allows to cover current needs and finance large-scale projects. The reduction of interest rates on deposits and loans during the third quarter of $\mathbf{2 0 2 0}$ is analyzed. The reasons for the decrease in the share of «non-performing» bank loans in 2020 are described. It is established that the intensification of bank lending is possible by reducing the level of riskiness of investment loans and improving approaches to managing existing risks. The process of minimizing risks involves identifying them, identifying sources and establishing the amount of information needed to assess the level of risk; selection of criteria and determination of methods for assessing their level; analysis of risk management results.

In general, the activity of banks and the state of the country's economy undoubtedly depend on a rational and balanced state policy. Public policy should be aimed at encouraging investment activity, stimulating investment in the economy, ensuring the stability of the banking sector. The development of the banking sector in general and the stimulation of the bank's lending operations cannot develop without the lack of political and economic stability in the country.

Keywords: bank system; commercial bank; credit; credit policy; credit portfolio; State program «Accessible loans 5-7-9\%»; interest rate; nonperforming loans. 
Павелко О. В. ${ }^{[1 ;}$ ORCID ID: 0000-0002-2483-2245] К.э.Н., доцент,

Велигурская А. М. [1; ORCID ID: 0000-0002-4261-9739] соискатель высшего образования первого (бакалаврского) уровня

${ }^{1}$ Национальный университет водного хозяйства и природопользования, г. Ровно

\section{МЕХАНИЗМ КРЕДИТОВАНИЯ ЗАЕМЩИКОВ БАНКАМИ В СОВРЕМЕННЫХ ЭКОНОМИЧЕСКИХ РЕАЛИЯХ}

Статья посвящена исследованию особенностей банковского кредитования на современном этапе. Рассмотрена сущность понятий «банковский кредит» и «банковское кредитование». Выделены этапы кредитного процесса банка для предоставления ссуд заемщикам. Установлены значение, задачи и основные составляющие кредитной политики банка. Внимание уделено причинам негативной динамики количества коммерческих банков в Украине с 2016 по ноябрь 2020 г. Выявлено снижение доли кредитного портфеля в структуре Валового внутреннего продукта с 2016 по 2019 годы. Рассмотрена динамика структуры кредитования в разрезе видов деятельности и целей кредитов. Охарактеризованы особенности Государственной программы «Доступные кредиты 5-7-9\%», что позволяет покрывать текущие потребности и финансировать масштабные проекты. Проанализировано снижение процентных ставок по депозитам и займам в течение III квартала 2020 года вследствие низкого уровня инфляции, смягчения монетарной политики и обеспечения ликвидности банковских учреждений Национальным банком Украины. Освещены рекомендации Национального банка Украины коммерческим банкам для облегчения финансового бремени для заемщиков и повышения эффективности управления проблемной кредитной задолженностью в связи со значительным падением доходов заемщиков, вызванным режимом изоляции. Указана причина уменьшения доли неработающих банковских кредитов в 2020 г.

Ключевые слова: банковская система; коммерческий банк; кредит; кредитная политика; кредитный портфель; Государственная программа «Доступные кредиты 5-7-9\%»; процентная ставка; неработающие кредиты. 